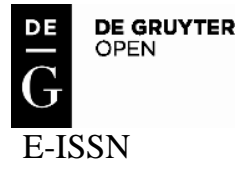

CIVIL AND ENVIRONMENTAL ENGINEERING REPORTS

CEER 2018; 28 (1): 016-025

2450-8594

DOI: $10.2478 /$ ceer-2018-0002

Original Research Article

\title{
COOLING OF A PROCESSOR WITH THE USE OF A HEAT PUMP
}

\author{
Zygmunt LIPNICKI ${ }^{1}$, Hanna LECHÓW ${ }^{1}$, Katarzyna PANTOŁ ${ }^{2}$ \\ ${ }^{1}$ University of Zielona Gora, Zielona Góra, Poland \\ ${ }^{2}$ The State Higher Vocational School in Głogów, Głogów, Poland
}

\begin{abstract}
In this paper the problem of cooling a component, in the interior of which heat is generated due to its work, was solved analytically. the problem of cooling of a processor with the use of a heat pump was solved based on a earlier theoretical analysis of authors of external surface cooling of the cooled component by using the phenomenon of liquid evaporation. Cases of stationary and non-stationary cooling were solved as well. The authors of the work created a simplified non-stationary analytical model describing the phenomenon, thanks to which heat distribution within the component, contact temperature between the component and liquid layer, and the evaporating substance layer thickness in relation to time, were determined. Numerical calculations were performed and appropriate charts were drawn. The resulting earlier analytical solutions allowed conclusions to be drawn, which might be of help to electronics engineers when designing similar cooling systems. Model calculations for a cooling system using a compressor heat pump as an effective method of cooling were performed.
\end{abstract}

Keywords: heat pump; cooling; processor; vapro compressor cycle; evaporation

\footnotetext{
${ }^{1}$ Corresponding author: University of Zielona Gora, Faculty of Civil Engineering, Architecture and Environmental Engineering, Z. Szafrana st 1, 65-516 Zielona Góra, Poland, e-mail: Z.Lipnicki@iis.uz.zgora.pl, H.Lechow@iis.uz.zgora.pl

${ }^{2}$ Corresponding author:The State Higher Vocational School in Głogów, Piotra Skargi st 5, 67-200 Głogów, Poland, e-mail: pantol@pwsz.glogow.pl
} 


\section{INTRODUCTON}

This paper is continuation of the paper [1] in which determining the conditions of liquid evaporation on the surfaces of studied components as an effective means of cooling the studied object, a general heat conduction equation in components with internal heat sources, which is widely discussed in scientific literature as evidenced by work [1]. One particular problem is determining the stationary conditions on the edge of a cooled object that has internal heat sources. One of the most effective methods of cooling is the use of the phenomenon of liquid evaporation on the surface of cooled components. In order to induce the phenomenon of evaporation on the surface of cooled components, the use of a compressor heat pump is very convenient. The phenomenon of coolant evaporation takes place in the heat pump's evaporator, which is called the thermodynamic cycle's lower heat source conducted in the heat pump. Designing cooling systems requires the ability to learn the process of heat flow in components submitted to cooling, while paying extra attention to the cooling surface.

Articles [2-4] present interesting research based on the original method of cooling selected components (MEMS - Micro-Electro-Mechanical Systems). The authors of the works applied a very effective method of cooling based on coolant evaporation on studied components, and a new method of transporting the liquid to a selected location within the computer based on the phenomenon of magnetohydrodynamics. The works are, above all else, of an experimental nature.

The issue of magnetic transport for laminar flow of appropriate coolants in pipes was solved theoretically in works $[5,6]$. The theoretical analysis of the process of microprocessor cooling was conducted in work [7] for cooling via coolant evaporation, while work [8] concentrated on variable load conditions via water stream cooling. Analytical solutions for stationary heat flow through a processor layer with internal heat sources and a layer evaporating liquid, whose thickness was determined a priori, was presented in the aforementioned work [7], which is in the form of a short announcement. There is a noticeable lack of theoretical works in scientific literature about studying the cooling of processors based on the coolant's surface evaporation and solving the full scientific problem, i.e. considering the non-stationary conditions of cooling selected computer components including the determination of evaporating liquid's surface thickness. Not enough attention is paid to temperature distribution within the processor. Processor temperature is an essential parameter determining the work quality of the device and it must not exceed the critical value. Currently, it is hard to acquire data, due to the rapid developments in computer technology, 
which defines the thermophysical properties of the material used in the production of processors; that knowledge is of the utmost importance for a full description of the phenomenon of heat conduction in studied components.

The purpose of this work is to present a theoretical study of heat flow in a processor with internal heat sources by determining its heat distribution and studying the effect of boiling liquid layer's thickness on the heat exchange process. There is a need for the creation of appropriate conditions for coolant evaporation on the surfaces of cooled components. One of the methods of delivering the boiling agent to a selected place within the computer and creating conditions in that place to enable coolant evaporation is the use of a CHP compressor heat pump. The aforementioned technology is proposed in the work.

\section{PROCESSOR WITH INTERNAL HEAT SOURCES COOLING MODEL}

The location of the studied component is described with a set of coordinates with the vertical axis ${ }^{y}$ having its beginning at the lower, horizontal coordinate of its surface (Fig. 1). The geometric dimensions of the component describe the height $H$ and frontal horizontal surfaces $F$. The unit's material has density $\rho_{C}$, specific heat $c_{C}$ and thermal conductivity $\lambda_{C}$. Inside the unit are evenly arranged internal heat sources with volumetric heat load $\dot{q}_{v}$. Heat flow in unit $\dot{q}$ determines temperature distribution $T$. By assumption, one side of the component is thermally isolated from the environment $\partial T \partial y^{-1}=0$, while on the other side the unit is in contact with a layer of evaporating liquid of thickness $\delta$. The liquid has density $\rho_{L}$, specific heat $c_{L}$ and thermal conductivity $\lambda_{L}$. The contact layer between the liquid and the unit is at contact temperature $T_{C}$. The phenomenon of liquid evaporation with vapor $\dot{m}_{S}$, heat of evaporation $h_{f g}$ and temperature of evaporation $T_{S}$ takes place on the free surface of liquid. A liquid of stream $\dot{m}_{l}$ flows through the layer of liquid at the time $t$.

The process of studied processor cooling can be split into the following special case: a stream of liquid inflowing to the liquid layer is equal to stream jet $\dot{m}_{L}=\dot{m}_{S}$. It corresponds to the constant thickness of liquid layer $h=$ const. ,$d h=0$. This case is a stationary process. If, apart from the equality of liquid and jet streams, the condition of the equality of streams of heat generated within the component $\dot{q}_{v}(t) H F$ and of heat received by cooling $\dot{m}_{S} h_{f g}$ is met, then a stationary process takes place. If the heat stream generated within the 
component is greater than the heat stream received, one observes an increase of temperature in time. Otherwise there is a decline in the component temperature.

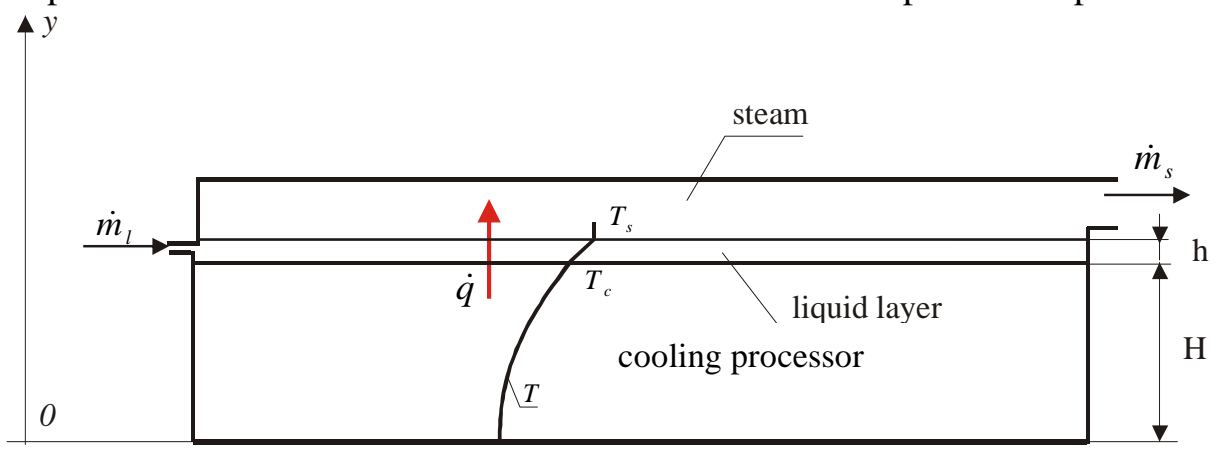

Fig.1. Cooling model of a processor with heat source

\section{STATIONARY PROCESS OF COMPONENT COOLING (STATIONARY PROCESS)}

In a stationary process, liquid and jet streams are equal $\dot{m}_{l}=\dot{m}_{S}$ while the other thermodynamic parameters do not change in time $t$. The solution to the stationary problem is based mainly on designating the temperature field in the studied component $T$ and liquid layer $T_{L}$ and the thickness of evaporating liquid layer $h$.

\subsection{Heat flow in the processor and liquid layer}

Heat flow in a processor with internal heat sources and in a liquid layer and the border conditions can be described by the Poisson equation and the Fourier equation in dimensionless forms like in paper [1]:

$$
\begin{aligned}
& \frac{d^{2} \theta}{d \tilde{y}^{2}}+\tilde{q}_{v}=0, \frac{d \theta}{d \tilde{y}}=0 \text { for } \tilde{y}=0 \text { and } \theta=\theta_{c} \text { for } \tilde{y}=1, \\
& \frac{d^{2} \theta_{L}}{d \tilde{y}^{2}}=0, \theta_{L}=\theta_{c} \text { for } \tilde{y}=1 \text { and } \theta_{L}=0 \text { for } \tilde{y}=1+\tilde{h} .
\end{aligned}
$$

where coordinate, unit temperature, contact layer temperature and internal heat source parameter are respectively designated:

$$
\tilde{y}=\frac{y}{H} ; \quad \tilde{h}=\frac{h}{H} ; \quad \theta=\frac{T-T_{s}}{T_{0}-T_{s}}, \quad \theta_{c}=\frac{T_{c}-T_{s}}{T_{0}-T_{s}} ; \quad \theta_{L}=\frac{T_{L}-T_{S}}{T_{O}-T_{S}} ; \quad \tilde{q}_{v}=\frac{\dot{q}_{v} H^{2}}{\lambda_{c}\left(T_{0}-T_{s}\right)}
$$


The solutions to differential equations (1) and (2) while meeting border conditions is equations

$$
\theta=\theta_{c}+\frac{\tilde{q}_{v}}{2}\left(1-\tilde{y}^{2}\right), \quad \theta_{L}=-\frac{\theta_{C}}{\tilde{h}} \tilde{y}+\frac{1+\tilde{h}}{\tilde{h}} \theta_{C}
$$

which presents the stationary parabolic heat distribution within the processor's layer. It depends on two parameters: temperature in the contact layer and the internal heat source. Stationary heat flow in a liquid layer of thickness $h$, temperatures $T_{C}$ and $T_{S}$ on the layer's borders, from which it is received by the evaporating liquid of heat streams evaporation $\dot{q}_{v a p}$ on one edge, while on the second one a heat stream from the cooled component is delivered. The problem of heat flowing through a liquid layer is described in a dimensionless form in the differential equation.

In the contact layer, in addition to temperature continuity $\left(\theta=\theta_{L}=\theta_{C}\right)$ there is also an equality of heat streams

$$
\left.\tilde{\lambda} \frac{\partial \theta}{\partial \tilde{y}}\right|_{\tilde{y}=1}=\left.\frac{\partial \theta_{L}}{\partial \tilde{y}}\right|_{\tilde{y}=1}
$$

where $\tilde{\lambda}=\lambda_{C} / \lambda_{L}$ means the relation of the thermal conductivity coefficient of the material of which the cooled component is built and that of the coolant.

From the condition of heat stream continuity (4) with the application of equations describing temperature fields (3), one receives a simple relation illustrating the relation between the evaporating substance's thickness $\tilde{h}$ and contact temperature $\theta_{C}$

$$
\theta_{C}=\tilde{h} \tilde{\lambda} \tilde{q}_{v}
$$

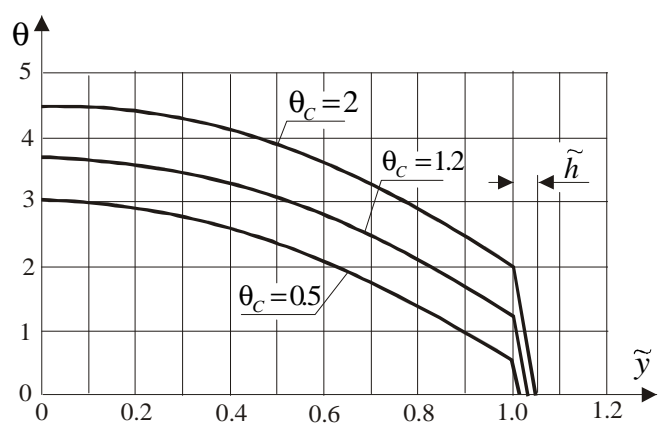

Fig. 2. Temperature distribution in a component with heat source for $\tilde{q}_{v}=5$ and $\tilde{\lambda}=8$ [1] 
The relation presented above leads to the conclusion that contact temperature increases with the increase in liquid layer's thickness. Temperature distribution in the studied component for exemplary contact temperatures $\theta_{C}$ and the corresponding thickness values of evaporating substances $\tilde{h}$ are presented in Figure 2.

The maximum temperature in the studied component processor is equal $\theta_{m}=\theta_{c}+\tilde{q}_{v} / 2$ and it is present on the edge of adiabatic surface $\tilde{y}=0$, which, in order to allow the device to work properly, must not exceed the acceptable value.

In stationary conditions, the heat stream conducted via the liquid layer is equal to the heat stream rejected via the evaporating liquid. This relation is described with equation

$$
-\left.\frac{\partial \theta_{L}}{\partial \tilde{y}}\right|_{\tilde{y}=1+\tilde{h}}=\tilde{q}_{v a p}
$$

in which a dimensionless evaporation parameter was designated using a complex expression

$$
\tilde{q}_{v a p}=\frac{\dot{m}_{s} h_{f g} H}{\lambda_{L}\left(T_{0}-T_{S}\right) F},
$$

where: $\dot{m}_{s}$ is evaporating liquid stream $h_{g f}$ is liquid evaporation heat, $F$ is frontal surface of the studied component.

By using equations (3) and (6), an equation can be formed determining the cooling agent's jet stream

$$
\dot{m}_{S}=\frac{\dot{q}_{v} F H}{h_{g f}}
$$

\section{COOLING SYSTEM}

In order to ensure appropriate conditions for an effective processor cooling, a CHP compressor heat pump (CHP) can be used as an element for a constituent set of cooled computer elements, in which a properly selected low-boiling agent (R-134a) is the working medium. Thermodynamic parameters of the low-boiling agent - temperature, evaporation pressure and flow - should correspond to processor cooling conditions resulting from a theoretical analysis performed earlier. 


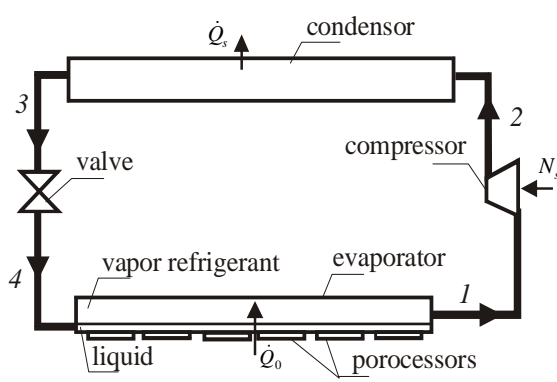

Fig. 3. Compressor heat pump schematic

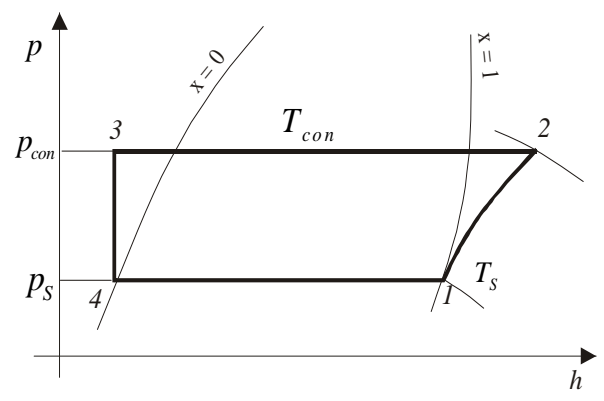

Fig. 4. Thermodynamic cycle of compressor heat pump in a Moliere graph

Figures 3 and 4 respectively present a compressor heat pump schematic and its thermodynamic cycle. Specifically marked points on the schematic and thermodynamic cycle (Moliere graph) describe different states of the lowboiling agent: 1 - saturated dry vapour (prior to entering the compressor) parameter, 2 - unsaturated vapour (after leaving the compressor and prior to entering the condenser) parameter, 3 - super-cooled liquid ( after leaving the condenser and prior to entering the throttle) parameter, 4 - thermodynamic agent liquid in a saturated state (prior to entering the evaporator) parameter. By using the CHP energy balance and thermodynamic chart one may determine the following values: $\dot{Q}_{\text {vap }}$ Cooling heat stream drawn in the evaporator in evaporation temperature $T_{S}, \dot{Q}_{C O N}$ condensation heat stream given up in the condenser at condensation temperature $T_{C O N}$ and compressor power demand $P$. The values of specific Linde cycle executing CHP circuit for cooling agent R$134 \mathrm{a}$ and for model G3420 Intel Pentium processor featuring $0,03 m \times 0,03 m \times 0,005 m$ dimensions and internal heat sources equal to $\dot{q}_{v}=20.18 \mathrm{MW} / \mathrm{m}^{3}$ (processor workload $48.5 \mathrm{~W}$ ) are presented in Table 1.

Table 1. CHP Linde cycle parameters

\begin{tabular}{|c|c|c|c|c|c|c|c|c|c|c|}
\hline $\begin{array}{l}\mathrm{N} \\
\mathrm{o} .\end{array}$ & $\begin{array}{l}T_{S} \\
{ }^{0} C\end{array}$ & $\begin{array}{l}T_{C} \\
{ }^{0} C\end{array}$ & $\begin{array}{l}T_{C O N} \\
{ }^{0} \mathrm{C}\end{array}$ & $\begin{array}{l}h_{f g} \\
\mathrm{~kJ} / \mathrm{kg}\end{array}$ & $\begin{array}{l}h_{1} \\
k J / k g\end{array}$ & $\begin{array}{l}h_{2} \\
k J / k g\end{array}$ & $\begin{array}{l}\dot{m}_{S} \\
\mathrm{~kg} / \mathrm{s}\end{array}$ & $\begin{array}{l}h \\
m m\end{array}$ & $\begin{array}{l}\dot{Q}_{\text {vap }} \\
W\end{array}$ & $\begin{array}{l}P \\
W\end{array}$ \\
\hline 1 & -5 & 18 & 20 & 199.2 & 393.2 & 418 & 0.000243 & 0.0402 & 48.5 & 6.03 \\
\hline 2 & 0 & 18 & 20 & 196.2 & 396.1 & 416 & 0.000247 & 0.0393 & 48.5 & 4.92 \\
\hline 3 & 5 & 18 & 20 & 1928 & 399.0 & 414 & 0.000252 & 0.0380 & 48.5 & 3.78 \\
\hline
\end{tabular}

The conditions within the evaporator are crucial. They are achieved thanks to heat pump's work. They should meet processor cooling conditions which are 
accepted in agreement with construction requirements. Evaporation temperature that is too low, may cause vapour dropping out from the surrounding air onto the computer elements' surfaces, which is detrimental to correct usage. As seen in Table 1, power demand for the compressor heat pump's drive is minimal. The evaporating liquid' layer thickness, which affects temperature drop from contact temperature do evaporation temperature is minimal as well.

\section{CONCLUSIONS}

This paper presents a solution for a simplified, author-proposed, quasi-stationary processor with internal heat sources cooling model based upon a classic stationary heat exchange that takes place in a circuit featuring an element with internal heat sources and an evaporating liquid layer. The theoretical model thus created allows for a realistic theoretical description of the phenomenon, i.e. to make contact temperature between the studied processor and the evaporating substance liquid layer and internal heat sources time-dependent. The work's result is the establishment of contact temperature and liquid layer thickness in a time function.

Existing classic theoretical solutions known in literature with differently set border conditions assume time-independent heat sources and a constant temperature at the edge of the area investigated. In terms of cooling, the contact temperature is drastically reduced in the initial moment and treated later as constant value.

Knowledge about the dependency of the contact temperature on time and the maximum temperature of the processor component, (which is dependent on contact temperature), is very important. The maximum temperature should not be greater than the border critical temperature, exceedance of which is unacceptable. Meeting this condition is decisive when it comes to the device functioning properly.

The application of the compressor heat pump for execution of evaporation process on the external surface of cooled component seems to be well justified. The power demand of a compressor heat pump CHP compressor heat pump's drive is negligible. An important part of the CHP cooling circuit is the thermodynamic agent's evaporation temperature, whose value must not be too low in order to avoid vapour dropping out from the surrounding air onto the surfaces of the computer elements.

Provided that the CHP works in invariable conditions, (i.e. both the evaporation temperature and the cooled element's received heat stream are constant), the temperature gradient on the edge of cooled element, the contact temperature and the thickness of evaporating liquid layer will be constant. 


\section{NOMENCLATURE}

\begin{tabular}{|c|c|c|}
\hline$a$ & {$\left[m^{2} / s\right.$} & heat diffusivity \\
\hline$c$ & {$[\mathrm{~J} /(\mathrm{kgK})]$} & specific heat at constant pressure \\
\hline$\lambda$ & {$[W /(m K)]$} & heat conductivity \\
\hline$H$ & {$[m]$} & height of the microprocessor \\
\hline$h$ & {$[m]$} & height of the liquid layer \\
\hline$\tilde{h}$ & {$[-]$} & dimensionless height of the liquid layer $=h / H$ \\
\hline$h_{f g}$ & {$[\mathrm{~J} / \mathrm{kg}]$} & heat of evaporation \\
\hline$\dot{q}$ & {$\left[W / m^{2}\right]$} & heat flux per area \\
\hline$\dot{q}_{v}$ & $W / m^{3}$ & source of heat \\
\hline$\tilde{q}_{v}$ & {$[-]$} & dimensionless source of heat $=\dot{q}_{v} H^{2} /\left(\lambda_{c}\left(T_{0}-T_{s}\right)\right)$ \\
\hline$\tilde{q}_{v a p}$ & {$[-]$} & dimensionless parameter of evaporation $=\dot{m}_{s} h_{f g} H /\left(\lambda_{L}\left(T_{0}-T_{S}\right) F\right)$ \\
\hline$K$ & {$[-]$} & evaporation parameter $=h_{f g} / c_{L}\left(T_{0}-T_{S}\right)$ \\
\hline$\dot{m}$ & {$[\mathrm{~kg} / \mathrm{s}]$} & stream of mass \\
\hline$y$ & {$[m]$} & coordinate \\
\hline$\tilde{y}$ & {$[-]$} & dimensionless coordinate $=y / H$ \\
\hline$t$ & {$[s]$} & time \\
\hline$\tau$ & {$[-]$} & dimensionless time, $=K a_{C} t H^{-2}$ \\
\hline$T$ & {$[K]$} & temperature \\
\hline$T_{0}$ & {$[K]$} & reference temperature (may be the initial temperature) \\
\hline$T_{S}$ & {$[K]$} & liquid fusion temperature \\
\hline$T_{L}$ & {$[K]$} & liquid temperature \\
\hline$T_{C}$ & {$[K]$} & contact temperature \\
\hline$\theta$ & {$[-]$} & dimensionless temperature, $=\left(T-T_{S}\right) /\left(T_{0}-T_{S}\right)$ \\
\hline$\theta_{C}$ & {$[-]$} & dimensionless contact temperature, $=\left(T_{C}-T_{S}\right) /\left(T_{0}-T_{S}\right)$ \\
\hline$\theta_{L}$ & {$[-]$} & dimensionless temperature, $=\left(T_{L}-T_{S}\right) /\left(T_{0}-T_{S}\right)$ \\
\hline$\rho$ & {$\left[\mathrm{kg} / \mathrm{m}^{3}\right]$} & density \\
\hline
\end{tabular}

\section{REFERENCES}

1. Lipnicki Z., Lechów H., Pantoł K.: Temperature profiles in a microprocessor cooled by direct refrigerant evaporation, Civil and Environmental Engineering Reports, 22(3), 111-126, 2016. 
2. Wang D.G., Muller P.K.: Improving cooling efficiency by increasing fan power usage, Microelectronics Journal 31, 765-771, 2000.

3. Darabi J.: An electrohydrodynamic polarization micropump for electronic cooling, Journal of Microelectromechanical Systems, 10, 98-105, 2001.

4. Darbi J., Ekula K.: Development of a chip-integrated micro cooling device, Microelectronics Journal 34, 1067-1074, 2003.

5. Ramos D.M., Cunha F.R., Sobral Y.D., Fontoura Rodrigues J.L.A.: Computer simulations of magnetic fluids in laminar pipe flows, Journal of Magnetic Materials 289, 238-241, 2005.

6. Moreau E., Paillat T., Touchard G.: Space charge density in electric and conductive liquids flowing through a glass pipe, Journal of Electrostatics 5152, 448-454, 2001.

7. Lipnicki Z., Waloryszek D.: Evaporation of the heterogeneous liquid flow forced by the magnetic field over a wall, The 15th Riga and 6th PAMIR Conference on Fundamental and Applied MHD, Liquid metal technologies, 283-286, 2005.

8. Lipnicki Z., Król F.: Dynamical cooling of semiconductor by contact layer. International Journal of Heat and Mass Transfer 48, 2922-2925, 2005.

\section{CHŁODZENIE PROCESORA ZA POMOCĄ POMPY CIEPŁA}

\section{Streszczenie}

Przedstawiono analityczne rozwiązanie równania chłodzenia jednostki, w której wytwarzane jest ciepło. $Z$ tego powodu opracowano uproszczony, niestacjonarny model określania rozkładu temperatury w jednostce, temperatury kontaktu między jednostką a warstwą cieczy oraz grubości warstwy parowania w funkcji czasu. Podano teoretyczną analizę zewnętrznego chłodzenia jednostki poprzez uwzględnienie zjawiska parowania cieczy za pomocą równań Fouriera i Poissona. Pokazano zarówno stacjonarny, jak i niestacjonarny opis chłodzenia. Uzyskane wyniki symulacji wydają się przydatne przy projektowaniu podobnych układów chłodzenia. Wykonywany jest również tryb obliczeniowy dla układów chłodzenia wyposażonych w pompę ciepła sprężarki, jako efektywnej metody chłodzenia.

Słowa kluczowe: pompa ciepła, chłodzenie, procesor, cykl sprężania pary, odparowywanie

Editor received the manuscript: 12.01.2018 